УДК 159.9:613 (075.8)

DOI https://doi.org/10.32838/2709-3093/2021.3/12

Сорока O.M.

Дунайський інститут

Національного університету «Одеська морська академія»

\title{
ТЕОРЕТИКО-МЕТОДОЛОГІЧНІ ПІДХОДИ ДО ДОСЛІДЖЕННЯ СТРЕСОСТІЙКОСТІ МОРЯКА ЯК ОДНІЕЇ 3 ОСНОВНИХ ХАРАКТЕРИСТИК ФУНКЦІОНАЛЬНОГО СТАНУ І СИСТЕМНОЇ ВЛАСТИВОСТІ ЙОГО ОСОБИСТОСТІ
}

\begin{abstract}
У статті подано результати аналізу теоретико-методологічних підходів до дослідження стресостійкості моряка як однієїз основних характеристик функиіонального стану і системної властивості його особистості. Зазначається, щзо дотепер категорія стресостійкості не набула однозначного трактування. Це поняття можуть замінювати на синонімічні: емоційна, психологічна, психофізіологічна, моральна, морально-психологічна, емоційно-вольова стійкість, стійкість особистості тощр.

У психології простежується ідея про подвійну природу стресостійкості, щзо проявляється в розгляді її як властивості, що впливає на результат діяльності, $і$ як характеристики, що забезпечує гомеостаз особистості як системи. А із иих позицій можна розглядати стресостійкість як показник діяльнісний і особистісний, який проявляе свою активність у разі невідповідності потенцій суб’єкта умовам чи вимогам конкретної діяльності. Роль цього компонента полягає у виробленні такої системи захисту особистості від стрес-чинників, яка забезпечила б стійкість особистості від розвитку в неї дистресового стану.

Робляться висновки, що успішність роботи, продуктивність прачі не залежать безпосередньо від психодинамічних характеристик поведінки, а проявляються у стилі виконання діяльності. Стильові характеристики залежсать від багатьох чинників, які осмислюються й оиінюються суб'єктом, набувають конкретного особистісного значення $і$ визначають його вибір. Інакше кажучи, особистість володіє власними індивідуально-психологічними властивостями, підбирає залежсно від їхньої очінки, забарвлює значенням ті чи інші способи досягнення иілей.
\end{abstract}

Ключові слова: стресостійкість, моряк, функиіональний стан, індивідуально-психологічні властивості, захист особистості. стрес-чинники.

Постановка проблеми. Професійна діяльність моряків здійснюється в умовах високого ризику для їхнього життя і здоров'я, оскільки відбувається в умовах комплексного впливу різноманітних стрес-чинників підвищеної інтенсивності, які можуть створювати екстремальні ситуації. Складність їхньої діяльності зумовлюється надзвичайно динамічними природно-кліматичними умовами морського середовища, високою технічною насиченістю та технічним станом обладнання, що використовується під час здійснення морських перевезень; тривалістю плавання; специфікою прояву людського чинника в умовах високого рівня фізичних та психічних навантажень, високої відповідальності за свої дії, нерегламентованого характеру морської праці; комплексним впливом різних чинників на організм i психіку моряка; ізольованістю в обмеженому просторі судна протягом плавання тощо. Саме через комплексний вплив цих та багатьох інших чинників імовірність виникнення нестандартних екстремальних ситуацій $є$ непередбачуваною та потенційною. Оскільки вплив екстремальних чинників професійної морської діяльності на організм та психіку моряка в умовах технічної системи судна $€$ постійним, вірогідність виникнення екстремальних ситуацій професійної діяльності виявляється досить високою. Тому їм необхідно розвивати стресостійкість, щоб навчитися витримувати високий рівень професійного навантаження, управляти власними емоціями у стресових ситуаціях для збереження психічного здоров'я, вчасно мобілізовувати внутрішні ресурси для подолання стресових ситуацій. Через це серед вимог до особистості моряка як фахівця морського транспорту, спеціаліста екстремального профілю, визначено базовий комплекс професійно важливих психологічних якостей, який відображає можливість 
здійснення професійної діяльності, що укладаються в поняття «безпечне мореплавство».

Аналіз останніх досліджень і публікацій. В України, а не лише за їі межами, уже сформувалась потужна плеяда науковців, що внесли суттєвий науковий доробок із проблеми професійного стресу та шляхів іiї вирішення. Різні аспекти стресостійкості досліджували Д. Олександров, В. Алещенко, I. Аршава, В. Барко, І. Ващенко, Г. Грибенюк, Н. Іванова, О. Колесніченко, В. Корольчук, В. Лефтеров, В. Медведєв, С. Миронець, Л. Мороз, Н. Оніщенко, В. Осьодло, Н. Потапчук, І. Приходько, Н. Родіна, О. Сафін, Р. Сірко, В. Стасюк, О. Тімченко, Ю. Широбоков, С. Яковенко. Психологічні аспекти стресостійкості у професійній діяльності морських фахівців розглядали Н. Басанець, Г. Броневицький, О. Даніленко, В. Корольчук, В. Крутецький, Т. Зайцева, Г. Криворотько, А. Побідаш, М. Рєпін, А. Страхов, О. Стрелкова, В. Чернявький, Л. Шафран та інші.

Постановка завдання. Мета статті - зробити аналіз теоретико-методологічних підходів до дослідження стресостійкості моряка як однієї 3 основних характеристик функціонального стану і системної властивості його особистості.

Виклад основного матеріалу дослідження. Як зазначає Т. Бохан, системні детермінанти стресу і стресостійкості мають онтогенетичну, етнокультурну та гендерну зумовленість і відображають в онтогенезі особливості становлення багатовимірного світу людини, пов'язані з рівнями системної організації свідомості, включаються в його детермінацію і сприяють формуванню окремих якостей особистості, що вказує на онтогенетичну природу стресу і стресостійкості [4, с. 372].

На думку І. Теплякової, стресові реакції «запускаються» як реальними подіями, так і уявними, у зв'язку із чим стійкість до стресу набуває неабиякої значущості, бо є важливим чинником збереження нормальної працездатності й ефективної взаємодії з оточенням. Вона вважає, що про високу стресостійкість можна говорити лише тоді, коли численні скрутні ситуації приводять до породження сприятливих первинних і вторинних оцінок, що, у свою чергу, перешкоджає виникненню руйнівних наслідків стресу і сприяє конструктивній взаємодії з ним. Дослідниця зазначає, що дотепер категорія стресостійкості не набула однозначного трактування. Це поняття можуть замінювати на синонімічні: емоційна, психологічна, психофізіологічна, моральна, моральнопсихологічна, емоційно-вольова стійкість, стійкість особистості тощо [16, с. 217].
Так, стресостійкість розглядається О. Катунінім як комплексна властивість людини, що характеризується ступенем адаптації індивіда до дії екстремальних зовнішніх і внутрішніх чинників, що виникають у процесі життєдіяльності, і проявляється в основних функціональних станах, рівні працездатності та демонстрованих моделях поведінки як характеристики, що впливають на ефективність і надійність спільної діяльності. Вона $\epsilon$ інтегративним чинником спільної діяльності співробітників і дозволяе зберігати в екстремальних умовах адекватність психічного стану й ефективність професійної діяльності, як індивідуальної, так і спільної $[8$, с. 8].

Визначення стресостійкості 3 позицій теорії інтегральної індивідуальності В. Мерліна пропонує С. Суботін: «Стресостійкість - це індивідуальна психологічна особливість, яка полягає у специфічному взаємозв'язку різнорівневих властивостей інтегральної індивідуальності, що забезпечує біологічний, фізіологічний і психологічний гомеостаз системи і веде до оптимальної взаємодії суб'єкта з навколишнім середовищем у різних умовах життєдіяльності і діяльності» [15, с. 39]. Під цим терміном він розуміє такі складники, як емоційна стійкість, психологічна стійкість до стресу, стрес-резистентність, фрустраційна толерантність. О. Церковський аналізує сучасні погляди на проблему та зазначає, що цей погляд на феномен стресостійкості є досить поширеним $[17$, с. $7-8]$. Якщо предметно-дієвий аналіз стійкості відображає результативні параметри діяльності, що характеризують зміни предмета праці, його ефективність та якість, то фізіологічний i психологічний підходи визначають процесуальну підтримку і забезпечення стійкої діяльності [2].

На один із суттєвих аспектів стресостійкості звертає свою увагу П. Зільберман і зазначає, що стійкість може бути недоцільним явищем, що характеризує відсутність адекватного відображення ситуації, що змінилася, що свідчить про недостатню флексибільність, адаптивність. Він пропонує власне трактування стресостійкості, розуміє під нею інтегративну властивість особистості, що характеризується такою взаємодією емоційних, вольових, інтелектуальних та мотиваційних компонентів психічної діяльності індивідуума, яка забезпечує оптимально успішне досягнення мети діяльності у складній емотивній обстановці [5].

Як можна зрозуміти з усіх наведених визначень стресостійкості, цей феномен (якість, риса, властивість) розглядається в основному 
3 функціональних позицій, як характеристика, що впливає на успішність діяльності. I лише в термінах С. Суботіна простежується ідея подвійної природи стресостійкості. Ця особливість проявляється в розгляді стресостійкості як властивості, що впливає на результат діяльності (успішність неуспішність), і як характеристики, що забезпечує гомеостаз особистості як системи. А із цих позицій можна розглядати стресостійкість як показник діяльнісний (зовнішній) та особистісний (внутрішній), який проявляє свою активність у разі невідповідності потенцій суб'єкта умовам чи вимогам конкретної діяльності. Роль цього компонента полягає у виробленні такої системи захисту особистості від стрес-чинників, яка забезпечила б стійкість (захищеність) людини від розвитку дістресового стану [17, с. 7-8].

Отже, виходячи з розуміння стресостійкості як однісї з основних характеристик функціонального стану і системної властивості особистості моряка, розглянемо індивідно-особистісні чинники його стресостійкості. Зокрема, багато дослідників констатують велику схильність до стресу людей типу А (коронарний тип). Так, О. Маклаков, С. Положенцев, Д. Руднєв зазначають високу ймовірність розвитку ішемічної хвороби серця в молодих людей цього типу в умовах тривалих психоемоційних навантажень [10]. Закордонні автори підкреслюють більшу схильність до стресу представників саме цього типу, відзначають також їхню схильність до неадекватної оцінки поставлених перед ними завдань, а також поспішність в ухваленні рішень [18].

За визначенням Б. Ананьєва, нейродинамічна група індивідуальних характеристик людини належить до класу первинних індивідуально-типових властивостей [1]. У зв'язку із цим С. Ільїн відзначає, що за невеликого та середнього ступенях психоемоційного напруження ефективність діяльності зростає в усіх людей, незалежно від того, які типологічні особливості прояву властивостей нервової системи їм притаманні. Однак за великого напруження раніше погіршується ефективність діяльності в осіб зі слабкою нервовою системою. Представники з високою виразністю сили нервових процесів виявляють велику стійкість до значного психоемоційного напруження, тоді як за середньої стресогенності суб'єкти зі слабкою нервовою системою демонструють високу ефективність діяльності, іноді навіть випереджають осіб із сильною нервовою системою. У разі збільшення інтенсивності діяльності, підвищення значущості результату праці спостерігається зниження ефективності діяльності в осіб зі слабкою нервовою системою. У представників сильного типу в таких умовах відбувається мобілізація ресурсів i, як іiі наслідок, зростання результативності діяльності. Загалом відзначено велику схильність осіб зі слабкою нервовою системою до стресу, він пояснює це тим, що у «слабких» суб'єктів у спокої енерговитрати є вищими, це свідчить про менші енергетичні ресурси, які можуть бути мобілізовані в умовах стресу [6].

О. Борисова довела, що суб'єкти з рухливістю нервових процесів відрізняються високою працездатністю в напружених умовах [3]. Особи з інертністю характеризуються зниженою активністю, високою тривожністю, замкнутістю, зривами в діяльності. Ці якості $\epsilon$ маркерами низької стресостійкості.

Л. Мітіна зазначає, що порушення балансу / урівноваженості нервових процесів супроводжується зниженням резистентності до стресу [12]. Це дає підстави стверджувати, що в більшості екстремальних видів діяльності, насичених несподіваними, надскладними, малостереотипними завданнями, великі шанси на успіх матимуть особи із сильною, рухливою і врівноваженою нервовою системою, що забезпечує високу стійкість до стресів. Але це положення не можна вважати універсальним щодо всіх видів професійної активності, оскільки мають місце стресогени, у яких продуктивність діяльності та протидія професійним стрес-чинникам опосередковуються особистісними й операційними характеристиками суб'єкта діяльності [17].

Як відомо, сукупність найважливіших властивостей індивіда та їхніх складних утворень у найбільш інтегративній формі реалізується у вигляді темпераменту. У різні часи дослідники висували різні теорії темпераменту залежно від розгляду ними чинників, які зумовлюють його прояви. Так, на думку Г. Айзенка, темперамент характеризується такими лінійно-ортодоксальними симптомокомплексами, як екстравертованість, а також інтровертованість і нейротизм, які мають безперервний і нормальний характер розподілу. Р. Кеттелл виокремив низку чинників, що належать як до темпераменту, так і до характеру, які стосовно один до одного $є$ незалежними й автономними в загальній структурі особистості. К.Г. Юнг і Г. Оллпорт визнають існування типів темпераменту, розглядають його як переривчасту, якісну характеристику індивідуальних відмінностей.

В. Небиліцин виокремлює три основні компоненти у структурі темпераменту: загальну 
психічну активність людини; руховий компонент; «емоційність» (вразливість, імпульсивність, емоційна лабільність) [13]. В. Мерлін під типом темпераменту розуміє закономірність зв'язків певних властивостей темпераменту, до яких він відносить такі психічні властивості, як: сензитивність; емоційну збудливість; активність; реактивність; співвідношення активності та реактивності; темп реакцій; ригідність - пластичність; екстравертованість - інтровертованість [11].

Більшість дослідників відзначають пряму односпрямовану залежність ступеня вираженості тривожності від схильності до стресу. Вони схильні вважати тривожність більш природно зумовленою властивістю людини, ніж характерологічною особливістю особистості, яке детермінує всю систему відносин людини і найтіснішим чином пов'язана 3 такими нейродинамічними $\mathrm{i}$ темпераментальними властивостями, як слабка нервова система, неврівноваженість нервових процесів, сензитивність і емоційна збудливість. На високу зумовленість емоційності індивідуальним складом людини вказує і С. Рубінштейн, який зазначає, що темперамент позначається в емоційній збудливості - у силі емоційного збудження, швидкості, 3 якою воно охоплює особистість, у стійкості, з якою воно зберігається [14].

Переважна кількість дослідників, які вивчають схильність людини до стресу в аспекті гендерного підходу, відзначають велику стійкість представників жіночої статі до емоціогенних чинників середньої інтенсивності та довготривалих. Вони краще справляються зі стресом завдяки біохімічним і фізіологічним особливостям жіночої природи, покликаної в біологічній еволюції відігравати основну роль у забезпеченні процесу спадковості, тоді як біологічне призначення чоловіків полягає у привнесенні мінливості до фенотипічної складової частини роду людського, а тому він є більш адаптивним до особливих, зокрема екстремальних, умов діяльності [7]. Деякі типові чоловічі або жіночі риси мають свої еволюційно-генетичні і фізіологічні передумови, інші риси формуються у процесі соціалізації та розвитку особистості. У цьому контексті психологічна стать радикально відрізняється від статі біологічної, але, незважаючи на це, можна припустити, що рівень стресостійкості осіб із переважанням того чи іншого психологічного гендерного начала буде визначатися умовами, у яких розгортається стресогенна ситуація, вимогами діяльності, а також ресурсами особистості як суб’єкта діяльності [17].
Більшість дослідників проблеми впливу мотиваційного чинника на ефективність діяльності підкреслюють іiі зумовленість законом Йєркса Додсона, водночас цей закон і тимчасове розгортання стадій розвитку стресу. за Г. Сельє, являють собою в загальних рисах однакову за конфігурацією залежність.

Важливе місце серед індивідно-особистісних чинників стресостійкості моряка посідає таке психічне новоутворення, як самоставлення. Воно конкретизовано в такому понятті, як «самооцінка», яка належить до центральних утворень особистості, до іiі ядра. У структурі відносин особистості самооцінці належить особливо важливе місце, бо вона напряму пов'язана із процесом соціальної адаптації особистості. Значущою особистісною особливістю, що підвищує стрестолерантність у напружених умовах діяльності, $\epsilon$ саме адекватна висока самооцінка.

Якщо особистість характеризує вершину всієї структури людських властивостей, то індивідуальність - іiі глибину, і один із каналів, через які індивідуальність має зв'язок із зовнішнім світом, поряд з індивідом і особистістю, - це суб’єктність людини. Саме через різні види діяльності у процесі суб'єкт-суб'єктних (спілкування) і суб'єктоб'єктних (праця, пізнання) відносин в основному формуються і проявляються індивідуальність та особистість. Найбільш точно відображається цей процес у стилі діяльності людини. Він є інтегральним ефектом взаємодії суб'єкта й об'єкта. Це провідне психічне утворення, яке детермінується як властивостями особистості, так і умовами середовища. Причому наявність такого стилю забезпечує людині найбільш ефективну адаптацію взагалі і здатність протистояти стресовим впливам зокрема. Успішність протидії чинникам професійного стресу залежить від сформованості індивідуального стилю діяльності, хоча ефективність самої діяльності водночас може бути і невисокою.

Суттєвою особливістю індивідуального стилю $€$ співвідношення орієнтовних і виконавчих дій. Є. Клімовим та його послідовниками доведено, що в одних людей орієнтовна діяльність $є$ більш розгорнутою і сильніше відособленою від виконавчих дій (в осіб з інертною і слабкою нервовою системою), в інших ця діяльність $€$ менш розгорнутою і здійснюється переважно через виконавчі дії (в осіб із рухливою і сильною нервовою системою) [9]. Для опису процесуального аспекту індивідуального стилю необхідно брати до уваги не лише внутрішні характеристики суб'єкта, a й зовнішній аспект - ситуацію здійснення 
діяльності. Що ж результативного аспекту індивідуального стилю, то традиційні уявлення про нього побудовано на однозначності трактування успішності як обов'язкової ознаки стилю. Але успішність може мати досить великий діапазон. Крім того, висока успішність в одному аспекті діяльності (продуктивний або якісний) може поєднуватися з невисокими показниками в іншому. До того ж індивідуальні відмінності результату не повинні трактуватися як відмінності в успішності. Необхідно звернути увагу і на зв'язок результативного і процесуального аспектів діяльності. В індивідуальному стилі він не $є$ однозначним.
Окремі особливості процесуального боку можуть по-різному відображатися на результатах діяльності. Тобто індивідуальні відмінності результату - це не показник неуспішності, а прояви різних рівнів розвитку індивідуального стилю.

Висновки. Отже, можна зробити висновок, що успішність професійної діяльності не залежить безпосередньо від психодинамічних характеристик поведінки особистості, а проявляється у стилі виконання нею цієї діяльності. Особистість має власні індивідуальні властивості, підбирає залежно від їхньої оцінки, наповнює значенням ті чи інші способи досягнення поставлених цілей.

\section{Список літератури:}

1. Ананьев Б. Избранные психологические труды. Москва : Педагогика, 1980. Т. 1. С. 58-62.

2. Бодров В. Психологический стресс: развитие и преодоление. Москва, 2006. 528 с.

3. Борисова Е., Логинова Г. Индивидуальность и профессия. Москва : Знание, 1991. 191 с.

4. Бохан Т. Культурно-исторический поход к стрессу и стрессоустойчивости : дис. ... докт. психол. наук. Томск, 2008. 394 с.

5. Зильберман П. Эмоциональная устойчивость оператора. Очерки психологии труда оператора. Москва : Наука, 1974. С. 138-172.

6. Ильин Е. Дифференциальная психология профессиональной деятельности. Санкт-Петербург : Питер, 2008. $432 \mathrm{c}$.

7. Каримова А. Взаимосвязь гендерных особенностей и стрессоустойчивости личности. Вестник Восточной экономико-юридической гуманитарной академии. 2013. № 6 (68). С. 55-60.

8. Катунин А. Стрессоустойчивость как интегративный фактор совместной деятельности сотрудников служебных коллективов : дис. ... канд. психол. наук. Москва, 2016. 178 с.

9. Климов Е. Индивидуальный стиль деятельности в зависимости от типологических свойств нервной системы. Казань, 1969. 278 с.

10. Маклаков А., Положенцев С., Руднев Д. Психологические механизмы поведения типа А у молодых людей в период адаптации к длительным психоэмоциональным нагрузкам. Психологический журнал. 1993. № 6. С. 86-94.

11. Мерлин В. Темперамент как фактор трудовой деятельности. Очерк теории темперамента. Пермь, 1973. C. $148-167$.

12. Митина О., Перпер А., Абдуллаева Л. Исследование взаимосвязи личностных характеристик и динамики эмоциональной сферы в ситуации длительного стресса. Психологические исследования. 2019 T. 12. № 63. URL: http://psystudy.ru/index.php/num/2019v12n64/1701-rasskazova64.html.

13. Небылицын В. Психофизиологические исследования индивидуальных различий. Москва : Наука, 1976. 336 c.

14. Рубинштейн С. Проблемы общей психологии. Москва, 1973. 432 с.

15. Субботин С. Устойчивость к психическому стрессу как характеристики метаиндивидуальности учителя : дис. ... канд. психол. наук. Пермь, 1992. 152 с.

16. Теплякова И. Формирование стрессоустойчивости как актуальная проблема студентов-первокурсников вуза. Азимут научных исследований : педагогика и психология. 2018. Т. 7. № 1 (22). С. 216-219.

17. Церковский А. Современные взгляды на проблему стрессоустойчивости. Вестник Витебского государственного медицинского университета. 2011. Т. 10. № 1. С. 6-19.

18. Friedman M., Strieker E. The physiological psychology of huger: a physiological perspective. Psychological Review. 1976. Vol. 83. P. 401-431.

\section{Soroka O.M. THEORETICAL AND METHODOLOGICAL APPROACHES TO THE STUDY OF STRESS RESISTANCE OF A SAILOR AS ONE OF THE MAIN CHARACTERISTICS OF THE FUNCTIONAL STATE AND SYSTEMIC PROPERTIES OF HIS PERSONALITY}

The article presents the results of the analysis of theoretical and methodological approaches to the study of stress resistance of a sailor as one of the main characteristics of the functional state and systemic properties of his personality. It is noted that so far the category of stress resistance has not been unambiguously interpreted. 
This concept can be replaced by synonymous: emotional, psychological, psychophysiological, moral, moral and psychological, emotional and volitional resilience, resilience of the individual, etc.

In psychology there is an idea of the dual nature of stress, which is manifested in its consideration as a property that affects the result of activity, and as a characteristic that ensures the homeostasis of the individual as a system. And from these positions it is possible to consider stress resistance as an indicator of activity and personal which shows the activity at inconsistency of potentials of the subject to conditions or requirements of concrete activity. The role of this component is to develop a system of protection of the individual from stressors, which would ensure the stability of the individual from the development of distress.

It is concluded that success, productivity do not depend directly on psychodynamic characteristics of behavior, and manifested in the style of activity. In this case, stylistic characteristics depend on many factors that are understood and evaluated by the subject, acquiring a specific personal meaning and determining his choice. In other words, the individual has its own individual psychological properties, selecting depending on their assessment, coloring the meaning of certain ways to achieve goals.

Key words: stress resistance, sailor, functional state, individual psychological properties, personal protection, stressors. 